\title{
The Impact of Work Stress and the Work Environment in the Organization: How Job Satisfaction Affects Employee Performance?
}

\author{
Mochammad Munir Rachman \\ Lecturer of Faculty of Economics and Business, PGRI Adi Buana University, Surabaya, Indonesia \\ Email: hnn_munir@yahoo.com
}

How to cite this paper: Rachman, M. M. (2021). The Impact of Work Stress and the Work Environment in the Organization: How Job Satisfaction Affects Employee Performance? Journal of Human Resource and Sustainability Studies, 9, 337-354. https://doi.org/10.4236/jhrss.2021.92021

Received: May 16, 2021

Accepted: June 25, 2021

Published: June 28, 2021

Copyright () 2021 by author(s) and Scientific Research Publishing Inc. This work is licensed under the Creative Commons Attribution International License (CC BY 4.0).

http://creativecommons.org/licenses/by/4.0/ (c) (i) Open Access

\begin{abstract}
Research to date regarding job satisfaction such as comfort, love of work and working conditions are still a priority used in improving performance results. This is associated with too much workload. Unable to complete work due to stress factors, and less supportive work environment conditions. Managers just give up, but believe they can overcome, and finish. Several other organizations also faced the same thing. Therefore, the purpose of this study is to prove that job satisfaction can change the impact of work stress and work environment conditions on the performance of government employees in the Field of Appointment and Retired Employees in the Office BKN Region II Surabaya. This study uses an explanatory method by distributing questionnaires to 43 government employees in the Field of Appointment and Retired Employees in the Office BKN Region II Surabaya, and path analysis as the analysis technique. The results of the research findings show that work stress and work environment are able to increase employees' performance positively and give job satisfaction as an important role that employees can accept in achieving their performance. On the other hand, work stress and work environment conditions can indirectly improve performance by providing job satisfaction. This is because the manager's closeness with employees, always interacting, there is a concern, and the relationship between members in the work environment can bring comfort, thereby reducing stress. Conversely, employees feel like the job itself after obtaining satisfaction, and the results of their performance can be better.
\end{abstract}

\section{Keywords}

Work Stress, Work Environment, Job Satisfaction, Employee Performance 


\section{Introduction}

Employees have an important role as pengerak in the organization, in the end being able to produce the work performance achieved. Performance is a target or task given to an individual to complete it in the use of limited resources including time constraints (Altangerel et al., 2015). Work performance is behavior that is relevant to organizational goals, in individual control and is measurable, observable, developed, and others (Viswesvaran and Ones, 2000). This helps to identify and solve problems faced by employees in their work (Mackey and Johnson, 2000). Although employee performance has a contribution to the organization, it also has benefits for organizational goals. Problems that have become a phenomenon in organizations, especially service organizations in the government personnel environment, show that their performance is not in accordance with organizational expectations, the results have not reached the maximum.

The failure to improve employee performance in the organization is often constrained by employee satisfaction factors, the element of dissatisfaction with the work itself, due to work stress problems and an unsupportive work atmosphere or environment. This is because the work done is not in accordance with the wishes of the employee so that the work done cannot provide satisfaction with the work being done. Job satisfaction is the general attitude of an individual towards his work, a man with the level of job satisfaction high showed a positive attitude towards the job, a man less satisfied with the job done, this indicates a negative attitude toward the job (Robbins and Coulter, 2012).

Assessment of how the role of employees' job satisfaction can meet organizational goals. So far, employee satisfaction is still being discussed in organizations as an act of liking and disliking while on the job. Job satisfaction as an individual thing, each individual has a different level of job satisfaction according to the wishes and value systems they adhere to (Handoko, 2011), and the extent to which employees' job satisfaction fulfills their desires (Jayaweera, 2015). The higher the individual employee likes their job, the higher the level of satisfaction (Kurniawaty et al., 2019). Employee satisfaction whose assessment is higher with the activities carried out, is felt according to the wishes of individual employees, the higher the satisfaction achieved with their work activities (Rivai Zainal et al., 2018), while Safrizal (2013) states that job satisfaction has a direct influence on performance profession. This study calls job satisfaction having a positive influence in improving employee performance (Agustiningsih et al., 2016; Safaria, 2016). This shows that high-low job satisfaction has an influence on employee performance, and a positive relationship with employee job satisfaction is followed by increased performance results achieved (Saranya, 2014; Inuwa \& Muhammad, 2016; Shaju and Subhashinim, 2017). Employees who have high satisfaction have better performance in carrying out their duties than those who are dissatisfied with their work (Rachman, 2017).

Employee satisfaction does not only depend on the work itself but the work- 
load of employees that is not in accordance with the existing reality, so it has an impact on stress. According to Kreitner and Kinicki (2012) that behavioral, physical, and psychological responses can result in stressors or stressors. Because job stress has a significant influence in providing employee satisfaction with their work (Setyono et al., 2007), it is different from Kurniawaty et al. (2019); Jehangir et al. (2011), Mansoor et al. (2011), and Suhanto (2009) state that employee work stress has decreased when carrying out work activities even though the results are forced to obtain significant satisfaction, while the study of Venkataraman and Ganapathi (2013) also states that they are identical, but in stressful conditions, the physical environment has a significant positive impact because they are able to do activities in generating satisfaction with their work. This is synonymous with the study of Ur-Rehman et al. (2012); Essiam et al. (2015); and Riaz et al. (2016) are able to provide job satisfaction for the organization, while Khuong and Yen (2016) state that employee performance results decrease due to high work activity load, and this shows that work stress has a direct effect on employees which has an impact on decreasing work results, and the expected job satisfaction has not been able to improve job performance (Safrizal, 2013).

Stress problems are still felt when employees are getting bored. This is a challenge for organizational leaders. The more problems faced in the organization, the higher the risk of the workload faced by employees, such as work environment conditions, higher competitive characteristics, unable to utilize time optimally, uncontrollable factors, insufficient space to work, demands excessive demand from stakeholders, and others (Hall and Savery, 1986; Nasurdin et al., 2004). This is confirmed that employee dissatisfaction has already been experienced, because of the conditions with the work environment where the comfort as a workplace is not yet fulfilled. Therefore the work environment plays a major role in employee job satisfaction because it has a significant influence (Agbozo et al., 2017; Abualrub et al., 2016), and a healthy work environment is characterized by physical and psychological conditions, procedures, structures, relationships, and policies, which positively affects employee satisfaction, motivation, and performance in the workplace (Singh et al., 2011). A work environment that has all physical aspects of work, work physicology, and work regulations can affect job satisfaction and results (Schultz and Schultz, 2010), and the positive effect can increase employee satisfaction in carrying out work activities (Alif, 2015; Raziq and Maulabakhsha, 2015). While this paper confirms that there is an important influence on performance, because the performance results on the features of the physical environment can be shown from the accumulating evidence that the physical environment in which a person works can affect performance and job satisfaction (Brill et al., 1985; Clements-Croome, 2000; Davis, 1984; Dolden and Ward, 1986; Newsham et al., 2004; Vischer, 2007). Therefore, problems that exist in organizations, especially services for personnel, can be identified by raising several research questions including:

1) How does job stress affect job satisfaction? 
2) How does the work environment affect job satisfaction?

3) How does job satisfaction have an effect on employees performance?

4) How does job stress affect employees performance?

5) How does the work environment affect employees performance?

6) How does job stress affect employees performance through job satisfaction?

7) How does the work environment affect employees performance through job satisfaction?

\section{Literature Review}

\subsection{Work Stress}

Stress, as a response brought about by various external events, can take the form of positive experiences or negative experiences (Selye, 1976; Jagaratnam and Buchanan, 2004), and job stress is a model of emotional conditions and psychological reactions that occur in response to conditions inside and outside organization (Greenberg and Baron, 2010). Stress occurs due to individual interactions with other individuals. The occurrence of stress has a negative impact on the individual employee and the organization in general. The stress problems faced by employees are the nature of the job itself, which demanded employees to face the various types of behavior and individual characteristics of people (Azmi et al., 2016). According to Bashir and Ramay (2010), that stress is the force, pressure, or tension experienced by a person who is against the forces and tries to maintain their original state, while Robbins and Coulter (2012) say there is a close relationship between stress and performance. At certain stages, stress can increase employee performance, conversely the higher the stress level will have an impact on employee performance decline. Therefore, the stress problems faced by employees in an organization can be studied with several indicators including task demands, role demands, and personal demands (Robbins, 2008).

\subsection{Work Environment}

The work environment has been known as everything that is around workers, and affects employees in carrying out their duties (Nitisemito, 2015). Because the work environment has a significant influence on employee performance (Muchtar, 2016; Nadeem and Ahmad, 2017), and this emphasizes management to consider the conditions of the employee's work environment in order to be able to produce positive performance effects. The higher the conditions for a comfortable work environment in providing employee satisfaction, the higher the results of achieving performance (Widyaningrum and Rachman, 2019). Because the work environment is influenced by several factors that cause the decline in work activities in achieving performance, including noise, office furniture, ventilation and light factors, and should get more attention (Al-Omari and Okasheh, 2017), while the condition of decreasing employee work results in some organizational work environments are less supported by salary and benefits facilities, work relationships (Thyssen, 2010). According to Nitisemito (2015) 
that work environment factors are used as identification to improve work results, including a pleasant work atmosphere, an authoritarian level of employee superiors at work, having talent for opportunities to advance, calm atmosphere, sharing information in groups, and the atmosphere of the room or place where they work.

\subsection{Job Satisfaction}

Job satisfaction done by someone "likes or dislikes" the work being carried out can have a positive or negative impact, such as the type of work, work atmosphere, and interpersonal relationships (Gibson et al., 2011). According to Halkos and Bousinakis (2017), employee satisfaction can be greater, if you have a healthy workplace and employee welfare, while dissatisfaction brings very negative results for the company, while Robbins and Judge (2018) suggest that job satisfaction is also a positive feeling about work resulting from a broad characteristic evaluation. Another study by Adigun et al. (2017) revealed that job satisfaction has a significant effect both on employee performance. Conclusively, this job has tested the level of employee performance in relation to their level of satisfaction at the job. Likewise Abdulkhaliq and Mohammadali (2019), Torlak \& Kuzey (2019), Yuen et al. (2018), Kampkotter (2017), Bakotic (2016), and Platis et al. (2015) revealed that the relationship is positive and significant between job satisfaction and employee performance, and in fact, it can contribute in terms of performance so as to experience an increase in employee job satisfaction. This is indicated by the positive relationship between job satisfaction for the salary payment system, the type of work itself, promotion opportunities, organizational conditions, leadership style and physical conditions with employee performance. As the view of Robbins (2008) uses five measurement indicators, among others; satisfaction with superiors; satisfaction with colleagues; job satisfaction; satisfaction with promotional opportunities; and satisfaction with income.

\subsection{Performance}

Performance is the strength of organizational performance management. Rachman et al. (2020) that performance management is the overall activity carried out to improve the performance of an organization or company, including the performance of each individual employee and work group in their work. This helps to identify and solve problems faced by employees in their work (Mackey and Johnson, 2000). According to Mathis and Jackson (2011), stating what employees do or don't do, and Dessler (2013), assumes performance management as a unique, goal-oriented and sustainable way of assessing and managing employee performance. Therefore, Robbins and Coulter (2012) assess the performance of organizational employees through quality, quantity, timeliness, effectiveness and independence for work. Although employee performance is a contribution to the organization, it also has many benefits. Because employees carry out duties and responsibilities that contribute to the achievement of their work 
(Robbins and Judge, 2018). This is done so that the desire of the organizational leadership can control the work results of employees. How high can produce quality work for the resulting performance. Because the achievement of high employee performance results is able to produce maximum work (Rachman, 2017), while Mangkunegara (2017) states performance is a work of quality, and quantity achieved by individual persons regarding the responsibilities and work tasks assigned by the organization.

This study was conducted to examine the effect of work environment and job stress on job satisfaction which has an impact on the performance of the employees of the Appointment and Retired Regional Offices of the Office BKN Region II Surabaya, so that the researchers provide an overview of the conceptual design of the research as shown in Figure 1 below.

\section{Research Methods}

The research design is used to detail important procedures in obtaining information about the sample needed in the preparation and the problems that must be solved in the research (Rachman, 2018). This research using an explanatory method because it aims to explain the causes of the relationship between variables by testing hypotheses (Rachman, 2018). A sample of 43 government employees in the Field of Appointment and Retired Employees in the Office BKN Region II Surabaya. In addition to testing the instrument, it also analyzes the data using a path analysis model to prove the phenomenon of the influence of independent variables on the dependent variable directly or indirectly (Rachman, 2019).

\section{Results and Discussion}

Data analysis on the measurement of each variable indicator item can be fulfilled if it has a Corrected Item-Total Correlation $>0.30$, the validity can be accepted or rejected, as shown in Table 1 below.

From Table 1, it is stated that the six items of work stress indicators analyzed have a corrected item-total correlation coefficient of 0.698 respectively; 0.857; $0.453 ; 0.692 ; 0.891 ; 0896>$ critical value 0.30 . Those all indicator items that are built in forming work stress can be overcome by employees so that the problems faced do not make work stress high, and the results are valid. For the seven work environment indicator items, the coefficient values for the corrected item-total

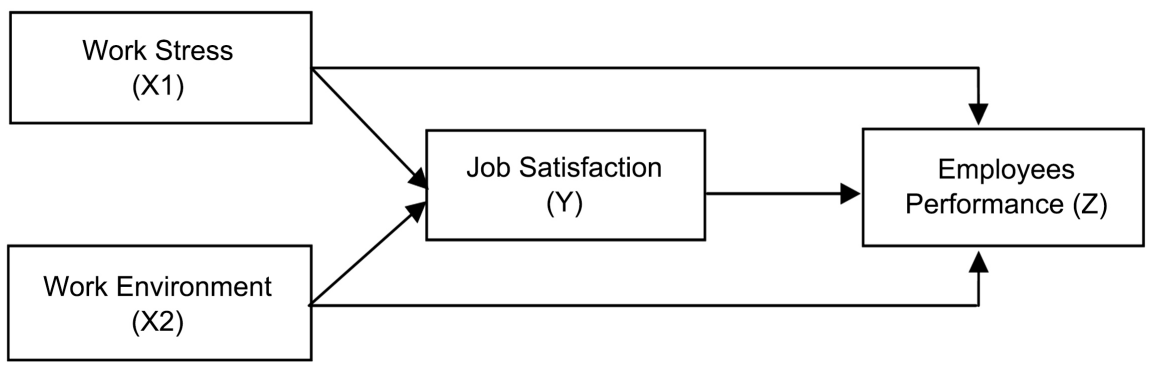

Figure 1. Conceptual framework model. 
Table 1. Instrument analysis on indicator items and reliable.

\begin{tabular}{|c|c|c|c|c|c|c|c|}
\hline \multirow{2}{*}{ Variable } & \multirow{2}{*}{ Item } & \multicolumn{5}{|c|}{ Corrected Item-Total Correlation } & \multirow{2}{*}{$\begin{array}{l}\text { Cronbach's } \\
\text { Alpha }\end{array}$} \\
\hline & & $\mathrm{X} 1$ & $\mathrm{X} 2$ & $\mathrm{Y}$ & $\mathrm{Z}$ & Description & \\
\hline \multirow{6}{*}{ Work Stress } & 1 & 0.698 & & & & Valid & \multirow{6}{*}{0.908} \\
\hline & 2 & 0.857 & & & & Valid & \\
\hline & 3 & 0.453 & & & & Valid & \\
\hline & 4 & 0.692 & & & & Valid & \\
\hline & 5 & 0.891 & & & & Valid & \\
\hline & 6 & 0.896 & & & & Valid & \\
\hline \multirow{7}{*}{ Work Environment } & 1 & & 0.645 & & & Valid & \multirow{7}{*}{0.904} \\
\hline & 2 & & 0.818 & & & Valid & \\
\hline & 3 & & 0.604 & & & Valid & \\
\hline & 4 & & 0.643 & & & Valid & \\
\hline & 5 & & 0.839 & & & Valid & \\
\hline & 6 & & 0.842 & & & Valid & \\
\hline & 7 & & 0.606 & & & Valid & \\
\hline \multirow{5}{*}{ Job Satisfaction } & 1 & & & 0.655 & & Valid & \multirow{5}{*}{0.817} \\
\hline & 2 & & & 0.401 & & Valid & \\
\hline & 3 & & & 0.664 & & Valid & \\
\hline & 4 & & & 0.670 & & Valid & \\
\hline & 5 & & & 0.651 & & Valid & \\
\hline \multirow{4}{*}{$\begin{array}{l}\text { Employees } \\
\text { Performance }\end{array}$} & 1 & & & & 0.808 & Valid & \multirow{4}{*}{0.805} \\
\hline & 2 & & & & 0.408 & Valid & \\
\hline & 3 & & & & 0.469 & Valid & \\
\hline & 4 & & & & 0.835 & Valid & \\
\hline Nilai Kritis $\alpha=0.05$ & & & & & & $>0.30$ & $>0.60$ \\
\hline
\end{tabular}

Source: Primary data analyzed by researchers.

correlation are 0.645 respectively; $0.818 ; 0.604 ; 0.643,0.839,0.842,0.606>$ critical value 0.30 . All of the indicator items in creating a comfortable atmosphere in the work environment can be built by employees as support in carrying out work activities so that they do not occur during work activities, and the results are valid. For the five indicator items, job satisfaction has a coefficient value for corrected item-total correlation, respectively $0.655 ; 0.401 ; 0.664 ; 0.670 ; 0.651>$ critical value 0.30 . That all indicator items formed in fulfilling work satisfaction have been facilitated properly by the leadership of the organization so that employees in carrying out work activities feel satisfied and comfortable, and the re- 
sults are valid. Then the four government employee performance indicator items have a corrected item-total correlation coefficient value of 0.808 each; 0.408 ; $0.469 ; 0.835>$ critical value 0.30 . Those are all indicator items that are able to support in producing high work and in accordance with their responsibilities can be fulfilled according to organizational goals whether produced with quality, quantity, timeliness or independence, so that the results are declared valid. Thus, all of the indicator items of the observed variables are shown through the coefficient value of the corrected item-total correlation which is stated as valid, so that it can be accepted empirically.

Furthermore, with the receipt of the corrected item-total correlation coefficient value of all variable indicator items of work stress, work environment, job satisfaction and performance of government employees in the field of hiring and retiring employees at the BKN Region II Surabaya Office which is analyzed as a measurement, and produces a coefficient value of Cronbach's Alpha. which is trusted or relied on practically from each variable indicator that is built and declared reliable because it has a Cronbach's Alpha value, work stress is $0.908>$ 0.60, the work environment has a Cronbach's Alpha value $0.904>0.06$, job satisfaction has a Cronbach's Alpha value $0.817>0.06$, and employee performance has a Cronbach's Alpha value of $0.805>0.06$. Thus, the results of the path model analysis are in accordance with the relationship model between variables based on the conceptual framework model that explains the effect of work stress and work environment on job satisfaction and employee performance, as shown in Figure 2.

Furthermore, from Figure 2, the model of the relationship between variables for the influence of work stress and work environment on employee performance through job satisfaction can be analyzed according to the sub-structure model for direct and indirect effects between variables shown in Table 2 below.

Based on Table 2, the indicated standardized coefficients beta on the variables of job stress of employees of the government of 0.538 , and its effect is also shown on the value of $t=5.889$ with a significant level of $0.000<0.05$. The results of this analysis state that job stress has a positive and significant direct effect on job satisfaction. The positive effect of work stress faced by government employees in carrying out their work activities has brought significant job satisfaction even though the workload faced is quite high but is able to complete it well. This cannot be separated from the continuous support and supervision of

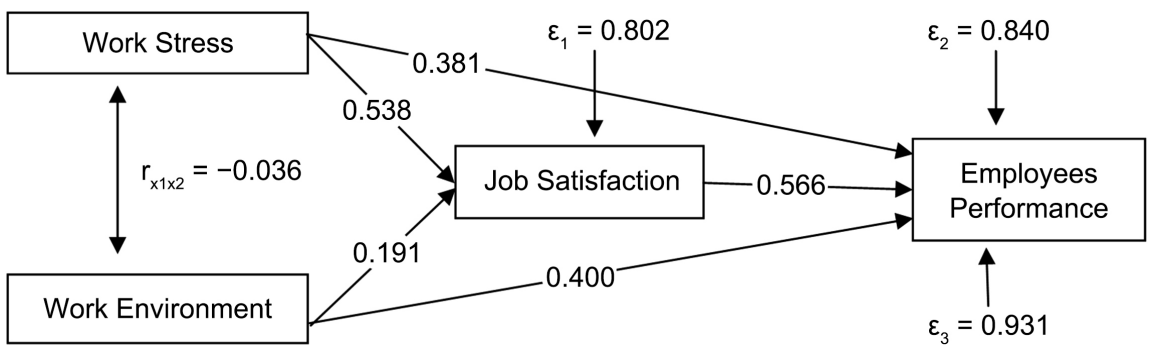

Figure 2. Model analysis of the relationship path between variables. 
Table 2. Analysis of the path coefficient of work stress and work environment on employee performance through job satisfaction.

\begin{tabular}{|c|c|c|c|c|c|c|c|}
\hline \multirow{2}{*}{ Variable Effect } & \multicolumn{3}{|c|}{ Causality Effect } & \multirow{2}{*}{ Test Result } & \multirow{2}{*}{ Description } & \multirow{2}{*}{$\mathrm{R}$} & \multirow{2}{*}{ R Square } \\
\hline & Direct & Inderect & Total & & & & \\
\hline $\mathrm{X} 1$ on $\mathrm{Y}$ & 0.538 & - & 0.538 & Ho rejected & Significant & \multirow[b]{2}{*}{0.597} & \multirow[b]{2}{*}{0.356} \\
\hline $\mathrm{X} 2$ on $\mathrm{Y}$ & 0.191 & - & 0.191 & Ho rejected & Significant & & \\
\hline $\mathrm{X} 1$ on $\mathrm{Z}$ & 0.381 & - & 0.381 & Ho rejected & Significant & \multirow[b]{2}{*}{0.543} & \multirow[b]{2}{*}{0.295} \\
\hline $\mathrm{X} 2$ on $\mathrm{Z}$ & 0.400 & - & 0.400 & Ho rejected & Significant & & \\
\hline Y on Z & 0.566 & - & 0.566 & Ho rejected & Significant & 0.566 & 0.320 \\
\hline $\mathrm{X} 1$ on $\mathrm{Z}$ & 0.538 & 0.305 & 0.597 & Ho rejected & Significant & & \multirow{2}{*}{0.114} \\
\hline $\mathrm{X} 2$ on $\mathrm{Z}$ & 0.191 & 0.108 & 0.626 & Ho rejected & Significant & & \\
\hline
\end{tabular}

Source: Primary data analyzed by researchers.

the leadership. The closer the leaders interact with their members, the better the attention and relationship between employees and their leaders, so that the work stress load they experience does not occur, on the other hand, employees are more comfortable with the work they are doing, and the resulting job satisfaction is better. The results of this study are in line with the research of Setyono et al. (2007), Ur-Rehman et al. (2012), Venkataraman and Ganapathi (2013), Bajpai et al. (2015), Essiam et al. (2015), Riaz et al. (2016), Bhanu and Sai Babu (2018), that work stress experienced by employees is not a burden but the work carried out during the organization provides job satisfaction in accordance with employee wishes, and on the contrary the results of this study do not support the results of Suhanto's (2009) research, Mansoor et al. (2011), and Dehghan et al. (2016), which revealed that job stress has a negative effect on job satisfaction because employees have not felt that they have received job satisfaction as expected.

Likewise indicated standardized coefficients beta on the environment variable employee of the government of 0.191 , and the effect is also shown on the value of $t=2.088$ with a significant level of $0.000<0.05$. The results of this analysis state that government employees' work environment has a positive and significant direct effect on job satisfaction. The positive influence of the work environment which is considered to have problems as a place for work activities is actually able to bring changes to a better condition. In addition, it is also shown that there is a comfortable environment with various facilities provided by the leadership of the organization so as to increase the satisfaction of their work results. The higher the employee's perception of comfortable working conditions, the better the employee will feel satisfied in carrying out work activities. This has perceived in employees the work environment provided by the leadership that has given employees satisfaction as a workplace activity. The results of this study are in line with the research of Ardakani et al. (2012), Almanae (2013), Widodo (2014), Essiam et al. (2015), Alif (2015), Raziq and Maulabakhsha (2015), Agbo- 
zo et al. (2017), and Bhanu and Sai Babu (2018), that a comfortable, calm and uninterrupted work environment around their workplace can have a positive effect on job satisfaction. Employees as long as they carry out their work duties that become their burden.

From Table 2, the indicated standardized coefficients beta on the variables of job stress of employees of the government of 0.381 , and its effect is also shown on the value of $t=4.032$ with a significant level of $0.000<0.05$. The results of this analysis state that job stress has a positive and significant direct effect on employee performance. The positive influence of work stress experienced by government employees in producing high performance can be shown by the quality and timeliness of completing their work. This is all due to the support of the leadership, taking persuasive actions, being close, and interacting in directing, guiding and accompanying them when doing their job duties, so as to produce satisfactory performance for the organization. Because the leadership's belief, work stress is considered to be able to interfere with employee work activities, not proven. The problem of work stress has not increased, employees continue to do work in accordance with the tasks they have received, and feel enjoy the greeting of carrying out their work. Until the time it takes, not according to his imagination, the ability, speed and accuracy of completing the job get higher and higher. Employees no longer think about their condition, jobs that are considered challenging are easily completed on time. The results of this study are in line with the research of Setyono et al. (2007), Hertanto (2011), Mansoor et al. (2011), that work stress which has a high enough load does not reduce his enthusiasm in completing his work. This positive influence still does not change everything that is considered difficult, so that the results of the work carried out further improve performance and under any conditions. On the other hand, this study does not receive support from research by Dehghan et al. (2016), Khuong and Yen (2016), because work stress has an effect that is not in line with the increase in performance, but it is increasingly producing decreased results.

Likewise indicated standardized coefficients beta on the environment variable employee of the government of 0.400 its influence, and shown also on the value of $\mathrm{t}=4.235$ with a significant level of $0.000<0.05$. The results of this analysis stated the work environment employees have direct positive and significant impact on employee performance. The influence of a positive working environment of the Appointment and Retirement of government employees in the Office BKN Region II Surabaya has environmental conditions that can increase employee work activities. This is inseparable from the role of leadership, supporting and directing what is the goal, adequate environmental conditions can still produce the desired performance. And, the success of the leadership in supporting its members remains a priority, employees also do not reject how the working environment conditions so far remain a comfortable condition. The interactions that the leaders build with their members are able to produce positive and significant results. Employees feel that they receive treatment and attention 
from the leadership every time they carry out work activities, even though the physical environment conditions are deemed appropriate and the conditions are supportive as activities, that is a positive income. In addition, the leadership also believes that the needs of employees in carrying out work activities need to be supported by various facilities related to the conditions of the work environment itself. The better the work needs provided by the organization, the more comfortable employees can carry out their work activities. And, leadership can manifest in employees through their own abilities, knowledge and expertise in the field of work itself. So that changes in employee behavior at work are not burdened, the existing facilities are very helpful, and the creation of conditions that are calm, comfortable, and without any feeling of boredom or disturbance. The results of this study are in line with the research of Hertanto (2011), Ardakani et al. (2012), Almanae (2013), Widodo (2014), Muchtar (2016), Nadeem and Ahmad (2017), that a calm, comfortable or uninterrupted work environment can influence employees in improving the performance of their work positively, and vice versa. The results of this study do not support the research of Al-Omari and Okasheh (2017), because the work environment that is considered to be able to produce comfort and calm without any disturbance is not positively accepted so that the performance results have not been able to show satisfactory results.

From Table 2, these indicated that the standardized coefficients beta in the variable job satisfaction of 0.564 its influence, and shown also on the value of $t=$ 6.140 with a significant level of $0.000<0.05$. The results of this analysis state that job satisfaction has a positive and significant direct effect on the performance of government employees. The positive effect of job satisfaction on the employees themselves is able to give a good impression in carrying out work activities, thus bringing significant changes to improving employee performance. Of course, this is an employee's success in carrying out their work, has satisfying results, and has a positive impact on employee morale in achieving high performance. This success is due to the role of leadership, high support, and interpersonal communication relationships that are able to bring significant changes, the results achieved are met according to organizational goals. The results of this study are in line with research by Setyono et al. (2007), Hertanto (2011), Ardakani et al. (2012), Widodo (2014), Saranya (2014), Inuwa \& Muhammad (2016), Shaju and Subhashini (2017), that the job satisfaction that is the expectation of employees has been fulfilled, the work is carried out according to their abilities and expertise to produce positive results for their work, so that the performance achieved by employees is in line with the quality and ability to complete their work effectively, high level, independence of work, and the timeliness of carrying out the tasks assigned by the organization.

From Table 2, the indicated job stress with standardized coefficients beta of 0.305 a positive influence and significant impact on the performance of government employees through work satisfaction. This positive effect of work stress brings success to the support of organizational leaders, provides enthusiasm for 
work, guidance and direction in producing high performance can provide good job satisfaction in supporting the organization. The magnitude of the effect of job stress indirectly on employee performance does not change the intention of employees in producing job performance with the support of providing job satisfaction from the leadership of the organization. This is thanks to the proactive leadership of the organization who always interacts, directs and supports employee activities to produce high performance even though the employee's condition is in an atmosphere of anxiety, distrust and perceived failure of the employee. The results of this study are in line with the research of Setyono et al. (2007), Safrizal (2013), that work stress that is a burden from tasks carried out to meet organizational goals is able to produce performance because organizational leaders always provide appropriate satisfaction and in accordance with what employees expect so as to avoid feeling anxious, disappointed, feeling, mental or bored with the work that is a burden. On the other hand, the results of this study do not support the research of Jehangir et al. (2011), Hanim (2016), and Ajayi (2018), because the work stress that becomes the workload of employees is not in line with organizational goals, so that job satisfaction is not optimal has not been able to significantly improve employee job performance.

From Table 2, it is shown that the work environment with standardization beta coefficient 0.108 has a positive and significant impact on the performance of government employees through job satisfaction. The positive influence of this work environment gives employees more enthusiasm to work, as desired by employees after obtaining job satisfaction that results in high performance. Satisfactory environmental conditions are supported by comfort, tranquility and freedom from the feeling of disturbance which is considered to be an obstacle for employees in producing the performance of the work being done. Because a comfortable work environment is supported by providing satisfaction with the work completed, according to organizational goals. The results of this study are in line with research by Ardakani et al. (2012), Almanae (2013), Widodo (2014), and Tjio and Anggela (2017), that a comfortable work environment and calm at work can change employee behavior, be more enthusiastic, focus on work, and without being bored with the work itself, although it is considered burdensome, so that the job satisfaction obtained at the job is able to increase the results of its performance.

\section{Conclusion}

The importance of the discussion of job stress, work environment, job satisfaction and employee performance of the government in this research need to have a special attention for the organization. Practically, in the environment of the Appointment and Retirement of government employees, in the Office BKN Region II Surabaya has shown a high contribution to changes and improvements in the work performance it has achieved. This contribution has a relationship between variables and the workload of employees, so that it can produce positive 
performance because the services provided for the appointment and retirement of government employees can be handled appropriately and smoothly. This is due to the closeness of the leadership to its members, what is done as a responsibility of monitoring, directing and supporting the ideas of its members. The closer the leadership interacts with its members, the better the employee's (members') attention and relationship with everyone in the organization, so that the work stress load experienced does not increase significantly. On the other hand, employees feel more comfortable with their working conditions, cooperation with peers, and with the work itself so that the resulting job satisfaction is better, and is able to improve the results of their performance. Likewise with the work environment which is the main need for employees in carrying out work activities so far, there are no obstacles found, employees feel comfortable, calm and disturbances around the workplace seem to enjoy. The conditions are more comfortable, the availability of work-related facilities is sufficient to satisfy employees' feelings of self, and the perceived job satisfaction increases enthusiasm and excitement at work. The better the needs provided by the organization in giving satisfaction to employees, the better the employees will get comfort, calmness and freedom from all disturbances that hinder the implementation of their work. Therefore, the positive influence of work stress and work environment that can affect employee performance in integrity with various things that is produced cannot be separated from employee job satisfaction in carrying out their duties.

\section{Recommendations}

The results and discussion of the research, it is hoped that the leadership of the organization will understand what employees face with the work that has been done. Employees should avoid the occurrence of work stress and turn into comfort. It needs attention and support who can always interact and provide things that can satisfy employees' work in improving the performance of the work done. In addition, the organization also needs to provide support for work conditions that are calmer, more comfortable without the hassle of causing employees to worry and provide facilities for working conditions that are more comfortable so that employees pay more attention to job satisfaction. By itself, employees are able to produce better performance.

\section{Research Limitations}

This research was conducted to understand and reveal the results of the work performance of government employees in the Office BKN Region II Surabaya. The sample used in this study is limited to the Field of Appointment and Retirement of Employees in the Office BKN Region II Surabaya from 4 (four) fields, because in the field under study has an important role in providing services to employees who have met the requirements as new employees or pre-service until retirement. Therefore, the researcher chose this field because it has duties and 
responsibilities in providing services to all employees so that it can be completed with high work results, and on time. As for further research, researchers should be able to design different models with different analyzes, if the same object can be developed again according to the needs of the organization.

\section{Conflicts of Interest}

The author declares no conflicts of interest regarding the publication of this paper.

\section{References}

Abdulkhaliq, S. S., \& Mohammadali, Z. M. (2019). The Impact of Job Satisfaction on Employees Performance: A Case Study of Al Hayat Company-Pepsi Employees in Erbil, Kurdistan Region-Iraq. Management and Economics Review, 4, 163-176. https://doi.org/10.24818/mer/2019.12-07

Abualrub, R., El-Jardali, F., Jamal, D., \& Al-Rub, N. A. (2016). Exploring the Relationship between Work Environment, Job Satisfaction, and Intent to Stay of Jordanian Nurses in Underserved Areas. Applied Nursing Research, 31, 19-23.

https://doi.org/10.1016/j.apnr.2015.11.014

Adigun, A. O., Oyekunle, I. A., \& Onifade, T. A. (2017). Influence of Job Satisfaction on Employees Performance in MTN Nigeria. Global Journal of Human Resource Management, 5, 54-60.

Agbozo, G. K., Owusu, I. S., Hoedoafia, M. A., \& Atakorah, Y. B. (2017). The Effects of the Work Environment on Job Satisfaction: Evidence from the Banking Sector in Ghana. Journal of Human Resource Management, 5, 12-18.

https://doi.org/10.11648/j.jhrm.20170501.12

Agustiningsih, H. N., Thoyib, A., Djumilah, H., \& Noijati, N. N. (2016). The Effects of Remuneration, Job Satisfaction and OCB on Employee Performance. Science Journal of Business and Management, 4, 212-222. https://doi.org/10.11648/j.sjbm.20160406.16

Ajayi, S. (2018). Effects of Stress on Employee Performance and Job Satisfaction: A Case Study of Nigerian Industrial Banking. https://doi.org/10.2139/ssrn.3160620

Alif, A. (2015). The Influence of Work Motivation, Career Development and Environment on Behoe Organizers (OCB) with a Separate Working Variant at the LPG Terminal. MIX Journal, 6, 291-309.

Almanae, M. (2013). Job and Job Satisfaction of Employees as Well as Customer Satisfaction Affect the Organizational Environment-An Applied Study at Bank Gumbouria, Libya. Acta. Universitatiasturae et Silvulturae Mendelianae Brunensis, 61, 1951-1956. https://doi.org/10.11118/actaun201361071951

Al-Omari, K., \& Okasheh, H. (2017). Effect of Work Environment on Job Performance: A Case Study of Corporate Engineering in Jordan. International Journal of Applied Engineering Research, 12, 15544-15550.

Altangerel, O., Ruimei, W., \& Bayandalai, D. (2015). Investigating the Effect of Job Stress on Performance of Employees. International Journal of Scientific \& Technology Research (IJSTR), 4, 276-280. https://www.ijstr.org/final-print/feb2015.pdf

Ardakani, A. E., Jowkar, B., \& Moghali, A. (2012). Effects of Organizational Environment on Performance and Job Satisfaction (University of Shiraz Case Study). Journal of Basic and Applied Scientific Research, 2, 8130-8139.

Azmi, F. S., Farah, Md Shahid, S. A., \& Alwi, A. (2016). The Relationship between Job 
Stress and Front-Liners' Job Performance in a Shared Service Center in Malaysia. International Journal of Social Science and Humanity, 6, 510-513.

https://doi.org/10.7763/IJSSH.2016.V6.701

Bajpai, J. V., Dave, T. V., \& Bajpai, S. (2015). Impact Study of Job Stress on Job Satisfaction of Employees Working in the Indian Banking Sector. International Journal on Quantitative Business, Economics and Management Applied Research, 1, 27-32.

Bakotic, D. (2016). Relationship between Job Satisfaction and Organizational Performance. Economic Research-Ekonomska Istrazivanja, 29, 118-130. https://doi.org/10.1080/1331677X.2016.1163946

Bashir, U., \& Ramay, M. I. (2010). Impact of Stress on Employees Job Performance: A Study on Banking Sector of Pakistan. International Journal of Marketing Studies, 2, 122-126. https://papers.ssrn.com/sol3/papers.cfm?abstract_id=2281979 https://doi.org/10.5539/ijms.v2n1p122

Bhanu, M. V., \& Sai Babu, P. C. (2018). Impact of Work Environment and Job Stress towards Job Satisfaction. IOSR Journal of Business and Management (IOSR-JBM), 20, $1-7$.

Brill, M., Margulis, S., \& Konar, E. (1985). Use Office Design to Increase Productivity (2 Vols.). Buffalo, NY: Workplace Productivity, Westinghouse Furniture Systems.

Clements-Croome, D. J. (2000). Creating a Productive Workplace. London: e \& FN Spoon. https://doi.org/10.4324/9780203027813

Davis, T. (1984). The Influence of the Physical Environment in the Office. Academy of Management Journal, 9, 271-283. https://doi.org/10.5465/amr.1984.4277654

Dehghan, H., Mobinyzadeh, V., \& Habibi, P. (2016). The Effects of Heat Stress, Job Satisfaction, Job Performance and Job Stress. Jundishapur Journal of Health Sciences, 8 , e36192. https://doi.org/10.17795/jjhs-36192

Dessler, G. (2013). Human Resource Management. London: Pearson Education, Inc.

Dolden, M., \& Ward, R. (1986). The Impact of the Work Environment on Productivity: A Process from the Workshop. Washington DC: National Science Foundation and Center for Architectural Research Consortium.

Essiam, J. O., Messah, M. E., Kekleli, L., \& Gyamfi, G. D. (2015). Effects of Job Stress on Job Satisfaction among University Staff: Analysis of Evidence from a Public University in GHANA. Journal of International Economics, Trade and Management, 3, 1-15.

Gibson, J. L., Ivancevich, J. M., Donelly Jr., J. H., \& Konopaske, R. (2011). Behavior, Structure, Process (14th ed.). London: McGraw-Hill Company, Inc.

Greenberg, J., \& Baron, R. A. (2010). Behavior in Organizations (10th ed.). London: Pearson Education.

Halkos, G., \& Bousinakis, D. (2017). The Effect of Stress and Dissatisfaction on Employees during Crisis. Economic Analysis and Policy, 55, 25-34. https://doi.org/10.1016/j.eap.2017.04.002

Hall, K., \& Savery, L. K. (1986). Tight Rein, More Stress. Harvard Business Review, 23, 1162-1164.

Handoko, T. H. (2011). Manajemen Personalia \& Sumber Daya Manusia. Edit isinya menjadi 2, Mold menjadi 18. BPFE Yogyakarta.

Hanim, M. (2016). Pengaruh Stres Kerja Terhadap Kepuasan Kerja Dan Dampaknya Terhadap Kinerja Karyawan Konstruksi Hull Di PT. DOK dan PERKAPALAN Surabaya. Jurnal Ilmu Manajemen, 4, 1-10.

Hertanto, E. (2011). Pengaruh Stresor, Kepuasan Kerja, dan Lingkungan Kerja terhadap Kinerja Karyawan PT. Putra Dharma Industri Pulo Gadung Jakarta Timur. Artikel Pe- 
nelitian Makalah. FE UPN Veteran Yogyakarta.

Inuwa, M., \& Muhammad, A. (2016). Impact of Job Satisfaction on Non-Academic Performance of Bauchi State University Gadau Staff: Moderating Effects of Physical Work Environment. IUARD International Journal of Economics and Business Management, 2, 60-77.

Jagaratnam, G., \& Buchanan, P. (2004). Balancing the Demands of School and Work: Stress and Being Hired by Hospitality Students. International Journal of Contemporary Hospitality Management, 16, 237-245. https://doi.org/10.1108/09596110410537397

Jayaweera, T. (2015). Impact of Work Environmental Factors on Job Performance, Mediating Role of Work Motivation: A Study of Hotel Sector in England. International Journal of Business and Management, 10, 271-278. https://doi.org/10.5539/ijbm.v10n3p271

Jehangir, M., Kareem, N., Khan, A., Jan, M. T., \& Seherwardi, S. (2011). The Effect of Job Stress on Job Performance and Job Satisfaction. Journal of Contemporary Research in Business, 3, 453-465.

Kampkotter, P. (2017). Performance Appraisals and Job Satisfaction. The International Journal of Human Resource Management, 28, 750-774. https://doi.org/10.1080/09585192.2015.1109538

Khuong, M. N., \& Yen, V. H. (2016). Investigate the Effect of Job Stress on Employee Performance-A Case Study in Dong Xuyen Industrial Zone, Vietnam. International Journal of Trade, Economics and Finance, 7, 31. https://doi.org/10.18178/ijtef.2016.7.2.495

Kreitner, R., \& Kinicki, A. (2012). Organizational Behavior. New York: McGraw-Hill Education.

Kurniawaty, Ramly, M., \& Ramlawati (2019). The Effect of Work Environment, Stress, and Job Satisfaction on Employee Turnover Intention. Management Science Letters, 9, 877-886. https://www.researchgate.net/publication/331827884 https://doi.org/10.5267/j.msl.2019.3.001

Mackey, K., \& Johnson, G. (2000). The Strategic Management of Human Resources. New Zealand, Auckland: Irwin/McGraw-Hill.

Mangkunegara, A. A. A. P. (2017). Manajemen Sumber Daya Manusia Perusahaan. The Mold 14. Bandung: Penerbit Rosda.

Mansoor, M., Fida, S., Nasir, S., \& Ahmad, Z. (2011). Impact of Job Stress on Employee Satisfaction Study in Pakistan Telecommunication Sector. Journal of Business Studies Quarterly, 2, 50-56.

Mathis, R. L., \& Jackson, J. H. (2011). Human Resource Management (13th ed.). Boston, MA: West-South.

Muchtar, M. (2016). The Influence of Motivation and Work Environment on the Performance of Employees. Sinergi: Jurnal Ilmiah Ilmu Manajemen, 6, 27-40. https://ejournal.unitomo.ac.id/index.php/feb/article/download/80/38 https://doi.org/10.25139/sng.v6i2.80

Nadeem, K., \& Ahmad, A. (2017). Impact of the Work Environment on Employee Performance Factors, Empirical Evidence from the Manufacturing Industry from Lahore. Journal of Managerial Science, 11, 422-436.

Nasurdin, A. M., Ramayah, T., \& Kemaresan, D. S. (2004). Organizational and Personality Effects on Manager's Job Stress: Is It Different for Malaysia and Women? International Journal of Business, 6, 251-274. https://doi.org/10.22146/gamaijb.5546

Newsham, G. R., Veitch, J., Charles, K. E., Clinton, J. G., Bradley, J. S., Shaw, C. Y., \& Readon, J. (2004). Environmental Satisfaction in an Open Environment: Relationships 
between Physical Variables. RR-153 Technical Report, Ottawa: Institute for Research in Construction, Canadian National Research Council.

Nitisemito, A. S. (2015). Manajemen Personalia. Jakarta: Ghalia Indonesia.

Platis, C., Reklitis, P., \& Zimeras, S. (2015). Relation between Job Satisfaction and Job Performance in Healthcare Services. Procedia-Social and Behavioral Sciences, 175, 480-487. https://doi.org/10.1016/j.sbspro.2015.01.1226

Rachman, M. M. (2017). The Influence of Work Culture on Job Satisfaction and Performance: A Study on Employees of Bank Satim in Surabaya, East Java, Indonesia. European Journal of Business and Management, 9, 30-39.

Rachman, M. M. (2018). Metodologi Penelitian. Pencetakan ketiga. Surabaya: Badan penerbit UNIPRESS, Universitas PGRI Adi Buana.

Rachman, M. M. (2019). Aplikasi Komputer Statistika: Sebagai Penunjang Analisis Data Penelitian Dengan SPSS. Pencetakan Ketiga. Surabaya: Badan penerbit Unipress, Universitas PGRI Adi Buana.

Rachman, M. M., Sugijanto, \& Samsiyah, S. (2020). The Effect of Transformational Leadership on the Performance of Employees with Motivation and Job Satisfaction as an Intervention (A study in the Office of the Irrigation Department working in Sidoarjo District, Indonesia). European Journal of Business and Management, 12, 12-23. https://iiste.org/Journals/index.php/EJBM/article/view/52872

Raziq, A., \& Maulabakhsha, R. (2015). Impact of Work Environment on Job Satisfaction. Procedia Economics and Finance, 23, 717-725. https://doi.org/10.1016/S2212-5671(15)00524-9

Riaz, M., Ahmad, N., Riaz, M., Murtaba, G., Khan, T., \& Firdous, H. (2016). The Impact of Job Stress on Employee Job Satisfaction. International Overview of Management and Business Research, 5, 1370-1382.

Rivai Zainal, V., Mansyur Ramly, H., \& dan Willy Arafah, T. M. (2018). Manajemen Sumber Daya Manusia Untuk Perusahaan Dari Teori Sampai Praktek. Edisi ke-3. Cetakan Ke 8. Jakarta: PT. Raja Grafindo Persada.

Robbins, S. P. (2008). Perilaku Organisasi. Edisi ke-9. Jakarta: PT. Indeks Grup Gramedia.

Robbins, S. P., \& Coulter, M. A. (2012). Management. New Jersey: Pearson Education.

Robbins, S. P., \& Judge, T. A. (2018). Organizational Behavior (18th ed.). London: Pearson Education.

Safaria, S. (2016). The Impact of Organizational Culture and Conflict on Employee Performance at Ptbangunan Jaya Ancol While Satisfaction Acts as a Variable Intervention. International Journal of Business Discovery and Management, 5, 45-55.

Safrizal, H. B. A. (2013). Pengaruh Stres Kerja Terhadap Kinerja Karyawan Dengan Variabel Intervening Kepuasan Kerja. Journal BISMA, 5, 69-75.

https://journal.unesa.ac.id/index.php/bisma/article/download/2811/1802.pdf https://doi.org/10.26740/bisma.v5n2.p69-75

Saranya, K. (2014). Influence of Job Satisfactionon Employees' Performance-A General Perspective. International Journal on Global Business Management and Research, 2. http://www.rajalakshmi.org/ijgbmr/downloads/IJGBMRMar14-Paper5.pdf

Schultz, D. P., \& Schultz, S. E. (2010). Psychology \& Work Today: An Introduction to Industrial and Organized Psychology (10th ed.). London: Pearson.

Selye, H. (1976). Stress in Health and Disease. Stoneham, MA: Butterworths.

Setyono, A., Rahardjo, M., \& dan Edy Rahardja, R. N. (2007). Analisis Faktor-Faktor Yang Mempengaruhi Stres Kerja Serta Pengaruhnya Terhadap Kepuasan Kerja dan Kinerja Salesman (Studi Kasus Pada PT. Adira Finance Cabang Bangkong Semarang). 
Jurnal Studi Manajemen \& Organisasi, 4, 70-80.

Shaju, M., \& Subhashini, D. (2017). A Study on Job Satisfaction on the Performance of Employees Working in the Car Industry, Punjab, India. Journal of Management Research, 17, 74-83.

Singh, S., Sharma, G. D., \& Sharma, R. (2011). Effect of Employee Involvement in Business Organisation. https://doi.org/10.2139/ssrn.1852018

Suhanto, E. (2009). Pengaruh Stres Kerja dan Iklim Organisasi Terhadap Turnover Intention dengan Kepuasan Kerja sebagai Variable Intervening (Studi di Bank Internasional Indonesia). Artikel Makalah Skripsi. Program Studi Magister Manajemen Program Pascasarjana Universitas Diponegoro Semarang.

Thyssen, L. (2010). Homing Behavior of Parablennius parvicornis (Pisces: Blenniidae). Anales Universitarios de Etología, 4, 25-30.

Tjio, M. O., \& Anggela, M. (2017). Analisis Pengaruh Lingkungan Kerja Terhadap Kinerja Karyawan Melalui Kepuasan Kerja Di Hotel "X” Di Surabaya. Jurnal Perhotelan dan Jasa Manajemen, 5, 192-201.

https://minio1.123dok.com/dt03pdf/123dok/000/802/802265

Torlak, N. G., \& Kuzey, C. (2019). Leadership, Job Satisfaction and Performance Links in Private Education Institutes of Pakistan. International Journal of Productivity and Performance Management, 68, 276-295. https://doi.org/10.1108/IJPPM-05-2018-0182

Ur-Rehman, M., Irum, R., Ijaz, N. T. Z., \& Salma, U. N. U. (2012). Impact of Job Stress on Employee Satisfaction: Study at Pakistani Private Universities. Journal of Business Studies Quarterly, 3, 50-56.

Venkataraman, P. S., \& Ganapathi, R. (2013). Study of Job Satisfaction Job Satisfaction among Small-Scale Industrial Employees. IOSR Journal of Business Management, 13, 18-22. https://doi.org/10.9790/487X-1331822

Vischer, J. C. (2007). Physical Effects of Environment on Job Performance: Against the Theory of the Stress Model. Journal of Stress and Health, 23, 175-184. https://doi.org/10.1002/smi.1134

Viswesvaran, C., \& Ones, D. S. (2000). Perspectives on Models of Job Performance. International Journal of Selection and Assessment, 8, 216-226. https://doi.org/10.1111/1468-2389.00151

Widodo, D. S. (2014). The Influence of Leadership and Work Environment for Job Satisfaction and Impact on Employee Performance (Study of Industrial Manufacturing in West Java). Journal of Sustainable and Sustainable Development, 5, 65-66.

Widyaningrum, M. E., \& Rachman, M. M. (2019). The Influence of the Work Environment, Organizational Commitment and Organizational Citizenship Behavior on Employee Performance and Motivation as Intervening (Studies in the Matahari Department Store Tbk. Tunjungan Plaza in Surabaya, Indonesia). European Journal of Business and Management, 11, 60-68.

https://iiste.org/Journals/index.php/EJBM/article/view/50739/52432

Yuen, K. F., Loh, H. S., Zhou, Q., \& Wong, Y. D. (2018). Determinant of Job Satisfaction and Performance of Seafarers. Transportation Research Part A: Policy and Practice, 110, 1-12. https://doi.org/10.1016/j.tra.2018.02.006 